\title{
Fresh and Hardened Properties of Self- Compacted Concrete at Different Curing Regimes
}

\author{
J. R. Al-Feel (Professor) \\ M. Abdul-Aziz \\ Dept. of Civil Engineering, Mosul University, Mosul, Iraq. \\ Email:jralfeel@yahoo.com
}

\begin{abstract}
The aim of this study is to compare the properties of three self-compacted concrete (SCC) mixes, with normal concrete mix. For the SCC mixes, the cement was replaced partially with either limestone dust or clinker waste dust. Compressive strength, tensile splitting, and flexural strength tests were conducted at ages of $3,7,14,28$, and 56 days to trace the strength development. Modulus of elasticity tests were conducted at 28-days. The test results showed that mixes containing lime-stone dust have better fresh properties than the other SCC mix. The compressive strength test results showed that the mix containing clinker waste powder give higher compressive strength. and mix containing eight percent limestone give higher tensile splitting strength and flexural strength than the mix has ten percent of limestone give for all curing regimes. The results showed that the modulus of elasticity is relatively lower than that for normal concrete and the voids volume in normal concrete is greater than that of SCC.
\end{abstract}

Keywords: Clinker dust, Compressive strength, Concrete, Fresh properties, Lime-stone

$$
\begin{aligned}
& \text { الخصائص الطرية والمتصلبة للخرسانة ذاتية الرص في ظروف مختلفة من الإنضاج } \\
& \text { جنان رشيد الفيل (أستاذ ) الهنسة المدنية، كلية الهندسة، جامعة الموصلى عبد العزيز الحربي } \\
& \text { الخلاصة }
\end{aligned}
$$

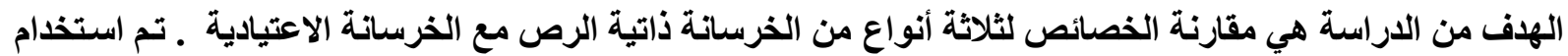

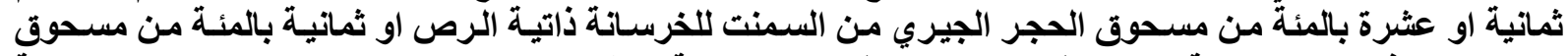

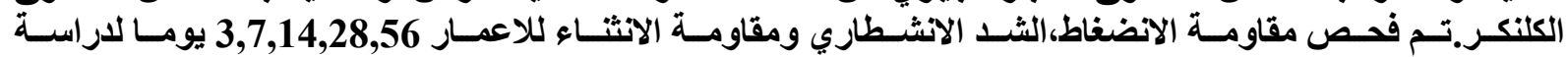

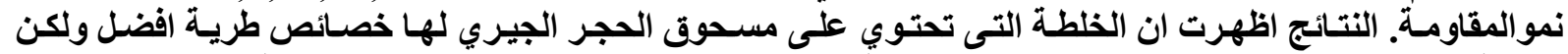

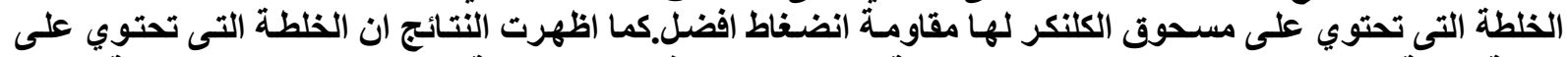

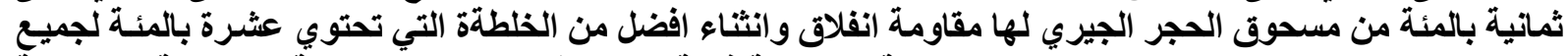

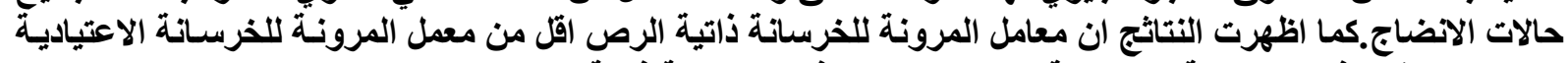
وحجم الفراغات في الخرسانة الاعتيادية اكبر من حجمها في الثرونة الخرسانة ذاتية الرصات الرصل 


\section{Introduction}

Self-Compacting concrete (SCC) was first developed in Japan more than 20 years ago and it was widely applied in architectural and structural building elements due to its ability to spread and passing through congested reinforcement without compaction. The main issues that promoted the development of SCC were the shortage of skilled labour and the emergence of heavily reinforced structures that made it difficult to sufficiently consolidate which is crucial for its durability.

Self-compacting concrete have high workability, low water cement ratio, and have high compressive strength at early ages [1].

There are so many researches on the kind of materials used to get the self-compacting concrete. In 2001 [2] (Bouzouban and Lachemi) used fly ash as a percentage of cement, and the mix have good workability and the presence of fly ash enhanced the compressive strength. The compressive strength increased as the percentage of water to cement plus fly ash decreases.

In 2005 Collepardi [3] used limestone dust in one mix and fly ash in another mix with the same cement content, and he found that both materials enhanced the compressive strength.

In 2005 Corinaldesi [4] replaced $10 \%$ of cement or sand by marble powder and he found that the replacement of $10 \%$ sand gave better results (in terms of compressive strength and workability) than replacing the cement.

In 2007 Felekoglu et al. [5] made five mixes with different percent of super plasticizers, and different water quantities ranging between (140-227) litre/ $\mathrm{m}^{3}$ to get a proper method of mix design for SCC. They concluded that a proper fresh SCC property can be obtained if the mixing time does not exceed 30 minutes and the casting is not later than 30 minutes after mixing. In 2008 Bager et al. [6] used five types of fine aggregates for eight mortar mixes, they concluded that proper grading of the sand enhanced the properties of self compacted mortar better than the type of sand.

The object of the present study is to obtain the fresh and hardened properties of selfcompacted concrete replacing eight, or ten percent of cement by lime-stone dust or eight percent of cement by clinker waste powder and to compare them with those of normal concrete.

\section{Materials}

Ordinary Portland cement complying with IQ5 [7], river sand with a fineness modulus of 2.74 complying with BS 882 [8], rounded river gravel with a maximum size of $12.5 \mathrm{~mm}$ complying with BS 882[8], lime stone powder passing sieve No. (200) replacing $8 \%$ or $10 \%$ of cement, and clinker powder passing sieve No.( 200) replacing $8 \%$ of cement were used. The chemical analysis for the lime stone dust and the clinker waste dust are shown in Table (1).

Table (1) Chemical analysis of the lime stone dust and clinker

\begin{tabular}{|l|c|c|}
\hline \multirow{2}{*}{ Chemical composition } & \multicolumn{2}{c|}{ Percentage } \\
\cline { 2 - 3 } & Limestone & Clincker \\
\hline Aluminium Oxide $\left(\mathrm{Al}_{2} \mathrm{O}_{3}\right)$ & 0.27 & 3.72 \\
\hline Silica Dioxide $\left(\mathrm{SiO}_{2}\right)$ & 6.29 & 12.54 \\
\hline Ferric Oxide $\left(\mathrm{Fe}_{2} \mathrm{O}_{3}\right)$ & 0.30 & 1.61 \\
\hline Calcium Oxide $(\mathrm{CaO})$ & 49.40 & 40.24 \\
\hline Sulphur Oxide $\left(\mathrm{SO}_{3}\right)$ & 0.25 & 0.46 \\
\hline Magnesium Oxide $(\mathrm{MgO})$ & 1.48 & 1.99 \\
\hline Losses & 42.04 & 39.45 \\
\hline
\end{tabular}


Sikament - NN as a super plasticizer (dark brown liquid with density $1.2 \mathrm{~kg} / \mathrm{l}$ ) was used with a dose of $2.5 \%$ by weight of cement as recommended by the manufacturer. Four mix proportions were used three for self-compacting concrete and one for normal concrete, as shown in Table (2) below. The washed gravel and the sand were mixed first, the cement with the limestone dust or clinker dust then added to the mixer and mixed with gravel and sand. Then the super plasticizer was mixed with water and added gradually to the mixer, and mixing continues till a homogeneous mix was obtained.

Table (2) Mix proportions

\begin{tabular}{|l|c|c|c|c|}
\hline Constituent $\left(\mathrm{kg} / \mathrm{m}^{3}\right)$ & M1 & M2 & M3 & M4 \\
\hline Cement & 440 & 440 & 400 & 420 \\
\hline Sand & 1000 & 1000 & 1065 & 650 \\
\hline Gravel & 810 & 810 & 836 & 1113 \\
\hline Lime stone powder & 36 & ------ & 40 & ----- \\
\hline Clinker powder & ------- & 36 & ------- & ------ \\
\hline Super plasticizer & 11 & 11 & 11 & ------ \\
\hline Water & 167 & 167 & 167 & 164 \\
\hline
\end{tabular}

Slump flow, V-funnel, J-ring, and L-box tests were conducted on the fresh mixes to check the specifications requirements of SCC.

Cubes $(100 \mathrm{~mm})$ were used to measure the compressive strength, cylinders $(150 x 300 \mathrm{~mm})$ to measure the tensile splitting strength and the modulus of elasticity, and prisms $(100 \times 100 \times 500 \mathrm{~mm})$ to measure the flexural strength. After the moulds were filled with concrete and levelled off, they were covered with a polythene sheet and left 24 hours in the laboratory, after which they were stripped from the moulds. Five curing regimes were used:

i- Three days water curing, and then kept in the laboratory till the testing time $(7,14,28$ and 56-days);

ii- Seven days water curing, and then kept in the laboratory till the testing time $(7,14,28$ and 56-days);

iii- Fourteen days water curing, and then kept in the laboratory till the testing time $(14,28$ and 56-days);

iv- Twenty eight days water curing, and then tested at 28 and 56-days;

v- Air curing and tested at 7, 14, 28 and 56-days.

\section{Results and Discussion}

\section{Properties of Fresh SCC}

The Slump flow test is used to measure the ability of spreading by filling the standard slump cone $(\mathrm{D} 1=100 \mathrm{~mm}, \mathrm{D} 2=200 \mathrm{~mm}$ and $\mathrm{H}=300 \mathrm{~mm}$ ) with SCC, Fig. (1), and left one minute and the cone is lift vertically and the time elapsed since the base of cone was lifted from the plate $(900 \times 900) \mathrm{mm}$ till the concrete reached $(500) \mathrm{mm}$ diameter was recorded, then two perpendicular diameters were measured as the concrete stopped spreading. The results are shown in Table (3). The three SCC mixes contain more paste and less aggregate than the conventional concrete mixes, and this contributes to the improved workability. The increase 

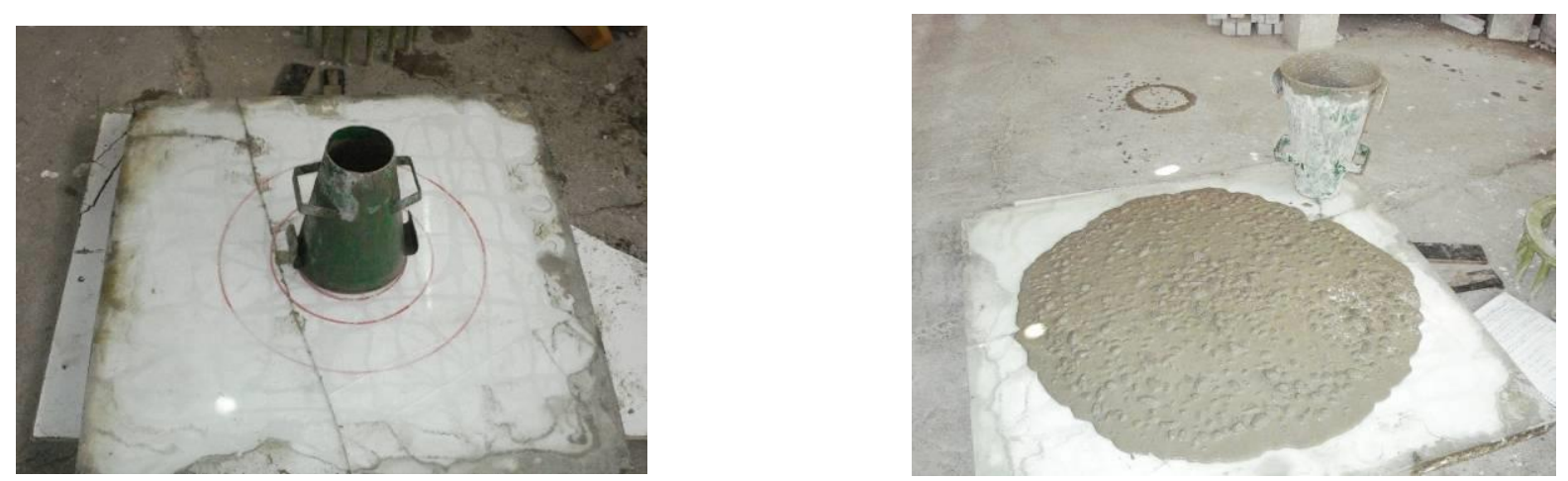

Figure (1) Slump flow test

in flowability, however, is essentially due to the addition of super plasticizer. The results show that Mix M1 gave an average diameter of $695 \mathrm{~mm}$ compared to $670 \mathrm{~mm}$ for mix M2, with a T500 time of 2.75 and 3.25 (secs) respectively, and mix M3 gave an average diameter of $720 \mathrm{~mm}$ with a T500 of 2.25 (secs), this means that the use of lime stone dust in SCC enhanced the workability better than the clinker dust and $10 \%$ limestone gave the best workability.

Table ( 3) Slump flow test results

\begin{tabular}{|c|c|c|c|c|c|c|}
\hline $\begin{array}{l}\text { Mix } \\
\text { No. }\end{array}$ & $\begin{array}{l}\text { T500 } \\
\text { (sec.) }\end{array}$ & $\begin{array}{c}\text { Specifications } \\
\text { Limits [9] }\end{array}$ & $\begin{array}{l}\text { Dmax } \\
(\mathrm{mm})\end{array}$ & $\begin{array}{l}\text { Dper } \\
(\mathrm{mm})\end{array}$ & $\begin{array}{l}\text { Davg. } \\
(\mathrm{mm})\end{array}$ & $\begin{array}{c}\text { Specifications } \\
\text { Limits [9] }\end{array}$ \\
\hline M1 & 2.75 & \multirow{3}{*}{ 2-5 (sec.) } & 700 & 690 & 695 & \multirow{3}{*}{$650-800(\mathrm{~mm})$} \\
\hline M2 & 3.25 & & 680 & 660 & 670 & \\
\hline M3 & 2.25 & & 730 & 710 & 720 & \\
\hline
\end{tabular}

The J-ring test results, which is used to measure the ability of passing of SCC consist of steel circle of 300 $\mathrm{mm}$ diameter with 16 bars $18 \mathrm{~mm}$ in diameter equally spaced, and used the same cone and plate as the slump flow test is shown in Fig. (2). The height of concrete from four sides $(\Delta h 1, \Delta h 2, \Delta h 3, \Delta h 4)$ and at the central $(\Delta h 0)$ were measured after the flow stopped then $\mathrm{Sj}$ is calculated as shown in Equation (1). Table (4) shows that the results for all the SCC mixes are complying with the specifications limits and mix M3 gave better results than mixes M1 and M2.

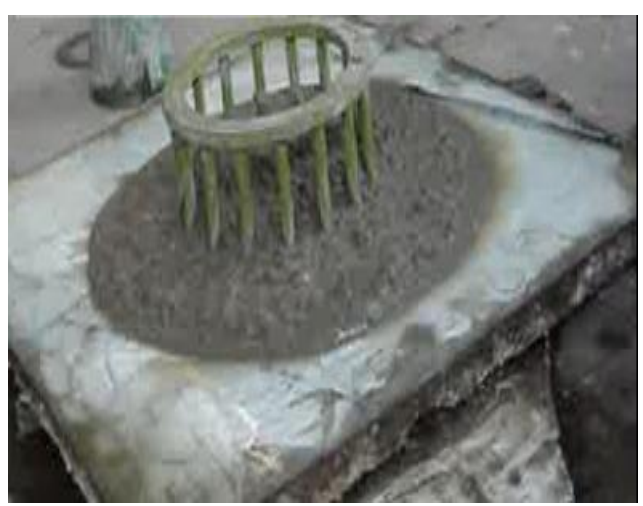

Figure (2) J-ring test

$$
\frac{(\Delta h x 1+\Delta h x 2+\Delta h y 1+\Delta h y 2)}{4}-\Delta h o \cdot B_{j}=S_{j}
$$

$B_{j}$ is the J-ring blocking step (mm)

Table (4) J-Ring test results

\begin{tabular}{|c|c|c|c|c|c|c|c|c|c|c|c|}
\hline $\begin{array}{l}\text { Mix } \\
\text { No. }\end{array}$ & $\begin{array}{l}\text { T500 } \\
\text { sec. }\end{array}$ & $\begin{array}{c}\text { Dmax } \\
\text { mm }\end{array}$ & $\begin{array}{c}\text { Dper } \\
\text { mm }\end{array}$ & $\begin{array}{c}\text { Davg. } \\
\text { Mm }\end{array}$ & $\begin{array}{c}\Delta h x 1 \\
\mathrm{~mm}\end{array}$ & $\begin{array}{c}\Delta h x 2 \\
\mathrm{~mm}\end{array}$ & $\begin{array}{c}\Delta h y 1 \\
\mathrm{~mm}\end{array}$ & $\begin{array}{l}\Delta h y 2 \\
\mathrm{~mm}\end{array}$ & $\begin{array}{r}\Delta h_{O} \\
\mathrm{~mm}\end{array}$ & $\begin{array}{r}S_{j} \\
\mathrm{~mm}\end{array}$ & $\begin{array}{r}S_{j}^{*} \\
\mathrm{~mm}\end{array}$ \\
\hline M1 & 3.55 & 680 & 660 & 670 & 121 & 121 & 120 & 122 & 109 & 12 & \multirow{3}{*}{$<15$} \\
\hline M2 & 4.15 & 650 & 640 & 645 & 122 & 120 & 121 & 121 & 106 & 15 & \\
\hline M3 & 3.11 & 705 & 685 & 695 & 122 & 123 & 121 & 122 & 114 & 8 & \\
\hline
\end{tabular}

*Reference (10) 
The L-box test is used to measure the ability of SCC passing through congested reinforcement and narrow sections by filling the vertical part with SCC and left one minute to settle then the gate opened to allow the concrere to pass around the bars to the horizontal part, Fig. (3). $\mathrm{H} 1$ and $\mathrm{H} 2$ were measured as the flow stopped. Table (5) shows the values of $(\mathrm{Pa}=\mathrm{H} 2 / \mathrm{H} 1)$, although Pa for mix M2 was lower than 0.8 , no blockage through the closely spaced bars was noticed. Mix M3

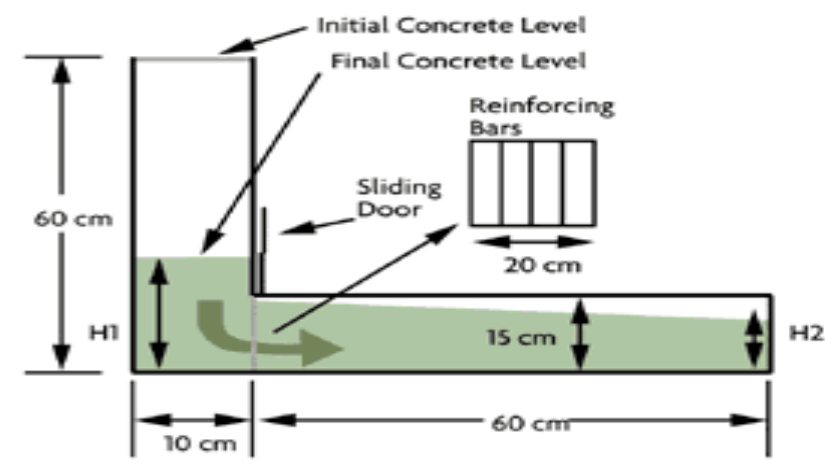

Figure (3) L-box test showed better performance than mixes M1 and M2 .

Table (5) L-box test results

\begin{tabular}{|c|c|c|c|c|}
\hline Mix No. & $\mathrm{H} 1(\mathrm{~mm})$ & $\mathrm{H} 2(\mathrm{~mm})$ & $\mathrm{Pa}=\mathrm{H} 2 / \mathrm{H} 1$ & $\begin{array}{c}\text { Specifications } \\
\text { Limits [10] }\end{array}$ \\
\cline { 1 - 3 } M1 & 102 & 83 & 0.813 & \multirow{2}{*}{$0.8<\mathrm{Pa}<0.85$} \\
\cline { 1 - 3 } M2 & 106 & 82 & 0.77 & \\
\hline M3 & 101 & 85 & 0.841 & \\
\hline
\end{tabular}

V-funnel test is used to measure the resistance of SCC to segregation Fig. (4). The V-shape part was filled with SCC and left for one minute then the gate at the bottom opened and the time elapsed to empty the concrete is recorded (T0), then the process is repeated the SCC is left on the V shape five minutes, and the time elapsed to empty the concrete from the V-shape is recorded (T5). Table (6) shows the test results. The results show that the value of (T0), and (T0-T5) for mix M1 and mix M3 are less than that of mix M2, which indicate that the presence of limestone dust and clinker in SCC enhance the resistance to segregation.

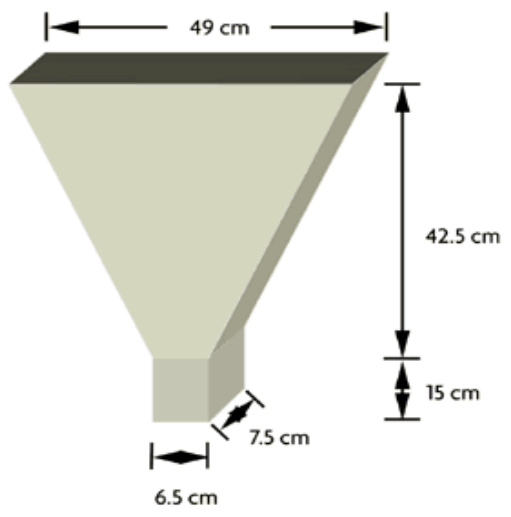

Figure (4) V-funnel dimensions

Table (6) V-funnel test results

\begin{tabular}{|c|c|c|c|c|c|}
\hline Mix No. & To(sec) & $\begin{array}{c}\text { Specification } \\
\text { limit(sec)[9] }\end{array}$ & T5(sec) & $\begin{array}{c}\text { T5-T0 } \\
(\mathrm{sec})\end{array}$ & $\begin{array}{c}\text { Specification } \\
\text { limit(sec)[9] }\end{array}$ \\
\cline { 1 - 1 } M1 & 9.5 & \multirow{2}{*}{$6-12$} & 11.4 & 1.9 & \multirow{2}{*}{$0-3$} \\
\cline { 1 - 1 } \cline { 4 - 5 } M2 & 10.1 & 12.6 & 2.5 & \\
\hline M3 & 8.2 & & 9.8 & 1.6 & \\
\cline { 1 - 1 } & &
\end{tabular}

\section{Properties of Hardened Concrete Compressive Strength}

Figure (5) shows the test results of the compressive strength at different ages for mixes M1, M2, and M3 for different curing conditions (each result is the average of three cubes). The results show that the compressive strength for air curing specimens is less than those in water curing for all the SCC mixes, and mix M2 gave high compressive strength than mixes M1 and 
M3. The water curing at different times have slight effect on the compressive strength for mixes M1 and M3 compared to the mix of normal concrete M4, Fig.(6) .The results also show that the compressive strength of SCC mixes (M1 andM3) are higher than that of normal concrete M4 for the same curing regime . Fig.(7) shows that for water curing the compressive strength at 14-days was (83.4-89.6)\% of the 28-days for Mix M1, (89.5-95.2)\% for Mix M2 , and (85.4-88.6)\% for Mix M3 while in the case of normal concrete it is (76.8-91.1)\%, and the percentage of the compressive strength at 7 days for air curing to 28 days compressive strength were $78.9 \%, 77.9 \%, 78.5 \%$ and $71.4 \%$ for mixes M1,M2,M3 and M4 respectively ,this indicate that SCC have higher strength development rate than normal concrete.

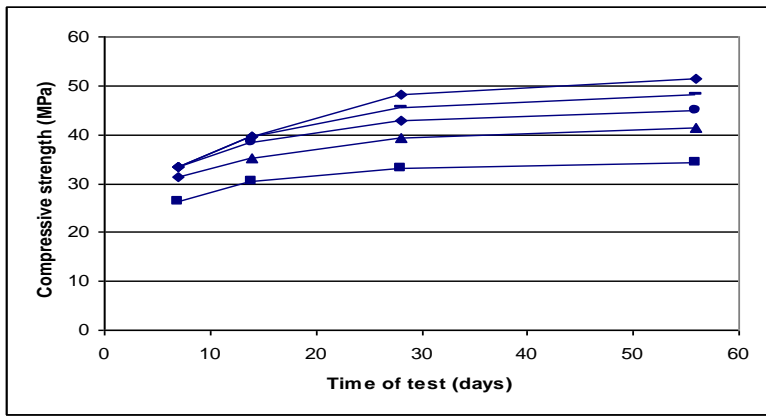

(a) Mix M1

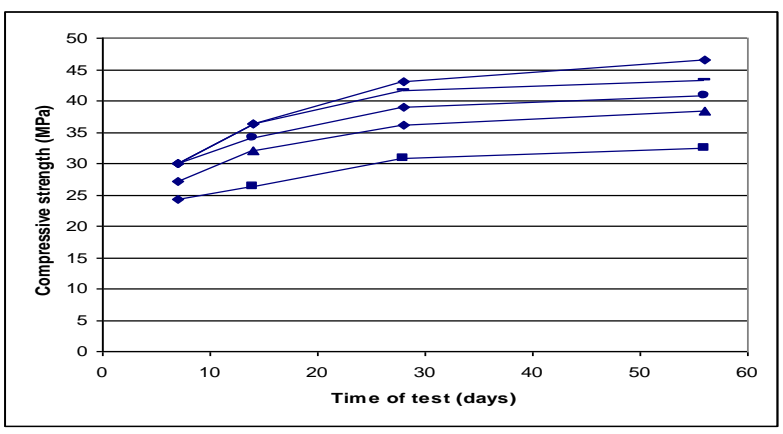

(c) Mix M3

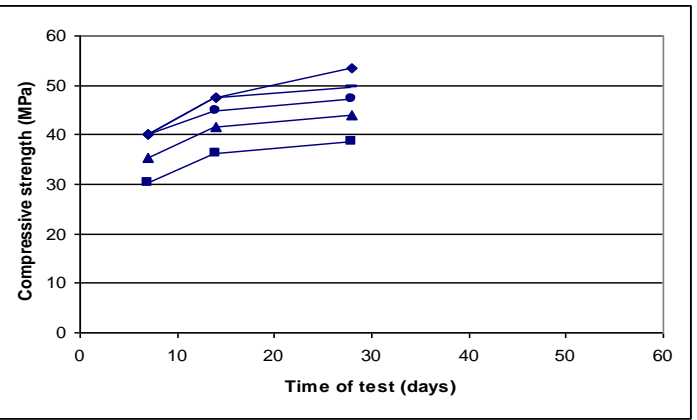

(b) Mix M2

air curing

A 3 days water curing

- 7days water curing

- 14days water curing

$\diamond$ 28days water curing

Fig (5) Variation of compressive strength with time for different curing regime,

(a) Mix M 1, (b), Mix M2, (c) Mix M3

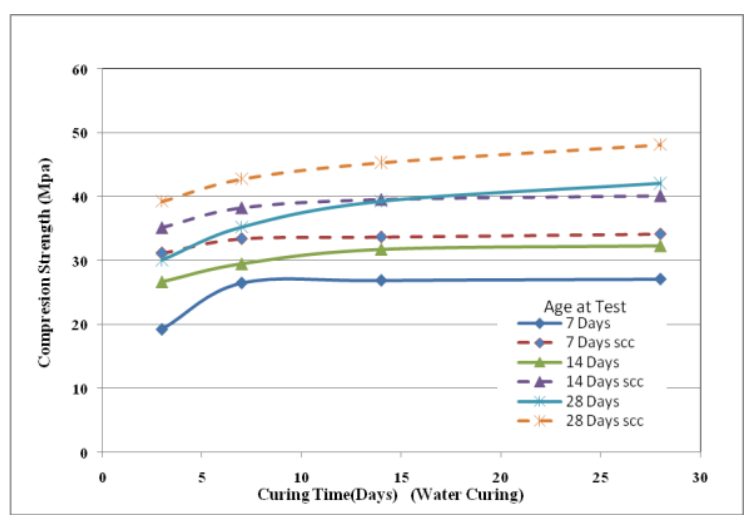

Mixes M1 and M4

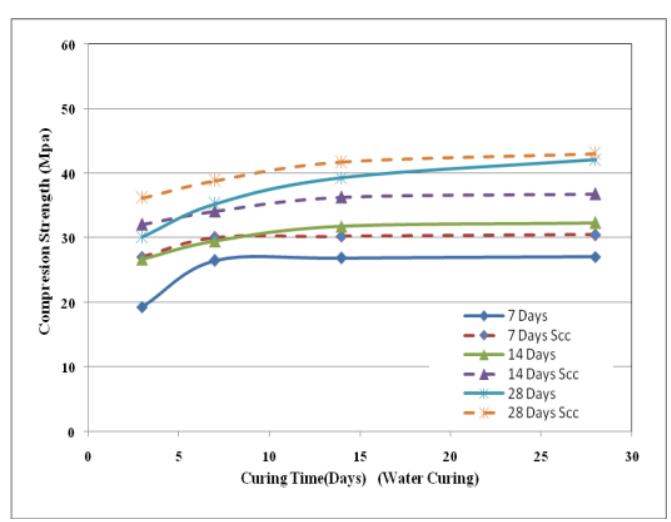

Mixes M3 andM4

Fig. (6) Comparison of the compressive strength for different curing regime for SCC and normal concrete 


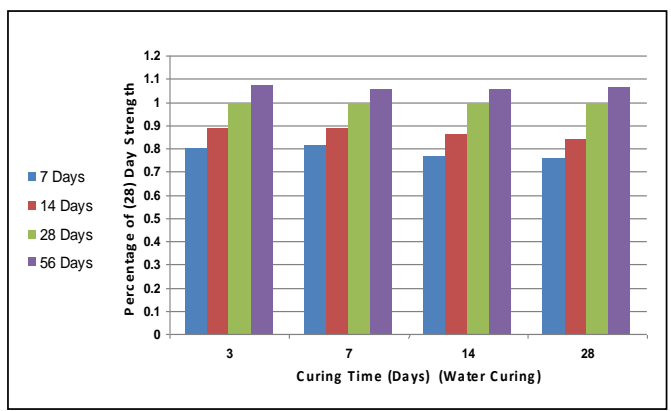

(a) Mix M1

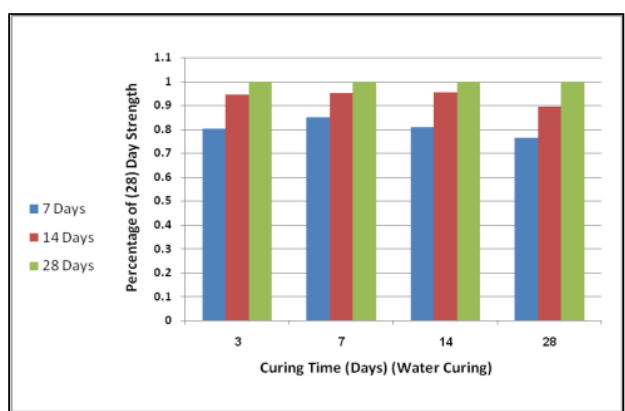

(b) Mix M2

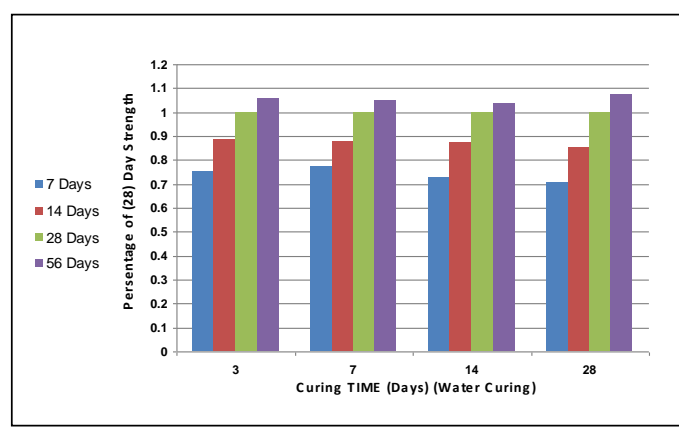

(c) Mix M3

Fig. (7) Percentage of the compressive strength to 28-days strength at different ages

Table (7) shows the comparison of the percentage increase of the compressive strengths of mixes M2 to M1 at different ages and curing conditions. The results show that the average increase of the compressive strength of M2 to M1 is (14) for all curing periods and conditions, this may be attributed to the composition of the clinker dust whose composition is similar to the cement composition.

Table (7) Comparison of the percentage increase in Compressive strength of mix with clinker to mix with limestone

\begin{tabular}{|c|c|c|c|c|}
\hline \multirow{3}{*}{$\begin{array}{c}\text { Curing } \\
\text { regime }\end{array}$} & Age (days) & 7 & 14 & 28 \\
\cline { 2 - 5 } & Curing time & \multicolumn{3}{|c|}{ Percentage increase in compressive strength } \\
\hline \multirow{3}{*}{ water } & 3 & 11.43 & 15.38 & 10.62 \\
\cline { 2 - 5 } & 7 & 16.58 & 14.5 & 9.26 \\
\cline { 2 - 5 } & 14 & 16.32 & 16.38 & 8.73 \\
\cline { 2 - 5 } & 28 & 16.42 & 16.07 & 10 \\
\hline \multicolumn{2}{|c|}{ Air curing } & 13.26 & 16.19 & 14.33 \\
\hline
\end{tabular}

\section{Tensile Splitting Strength}

Figure (8) shows the variation of the tensile splitting strength for mixes M1 and M3 with time for different curing regime. The results show that mix M1 gave higher tensile splitting strength than mix M3, and the ratio of tensile splitting strength of mixes M1 and M3 at the age of 28-days to that at the age of 56 days were about (93-95) \% for all curing regime, this indicate that the two SCC mixes have the same performance. 


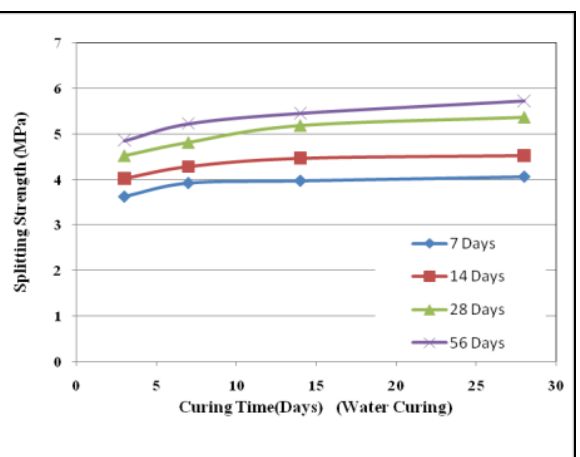

(a) Mix M1

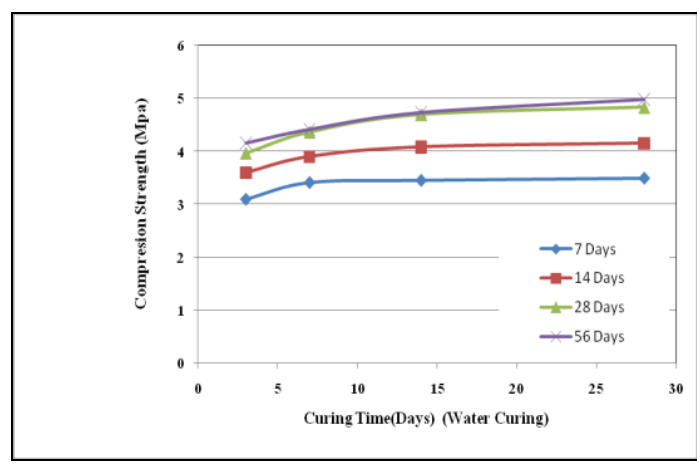

(b) Mix M3

Fig.(8) Variation of tensile splitting strength with time for different curing regime

Fig.(9) shows the comparison between splitting strength of SCC mixes and that of normal concrete for different curing regime and ages, the results show that both SCC mixes gave higher tensile splitting strength and have early strength. The ratio of the tensile splitting strength at the age of 14-days to that at 28-days were (84.3-88.9) \%,( 85.9-90.9) \% and (77.393.6) for mixes M1, M3 and M4 respectively, Fig.(10) for different curing regime, this indicate that the curing regime have more effect on the splitting strength of normal concrete M4.

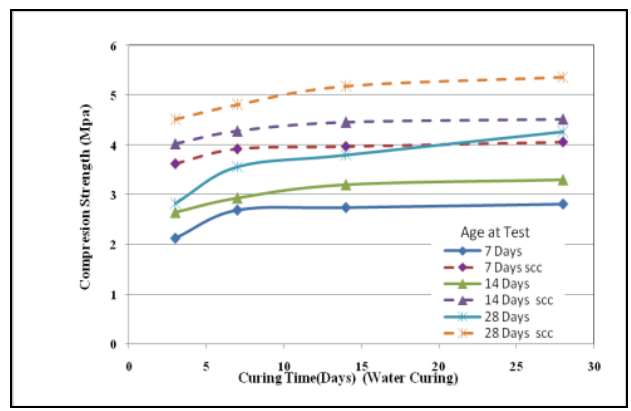

(a) M1 and M4

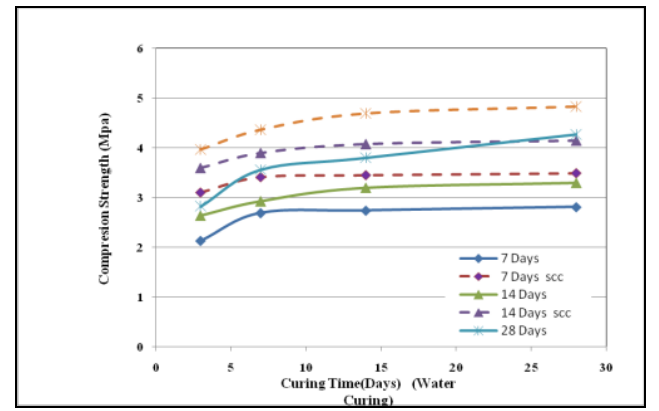

(b) M3and M4

Fig. (9) Comparison of the splitting strength of SCC and normal concrete

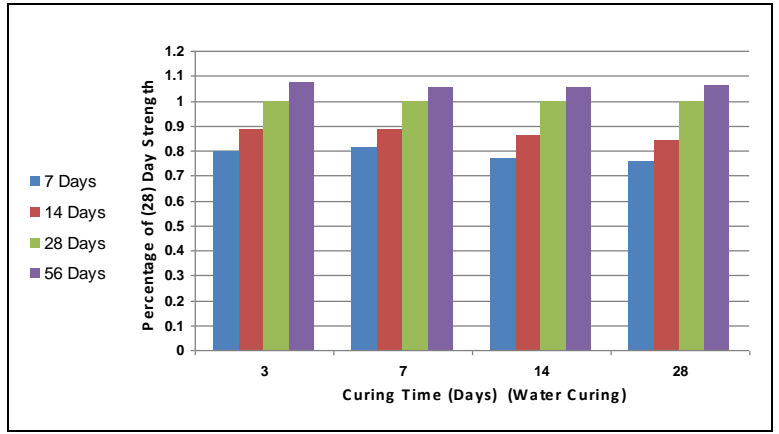

(a) Mix M1

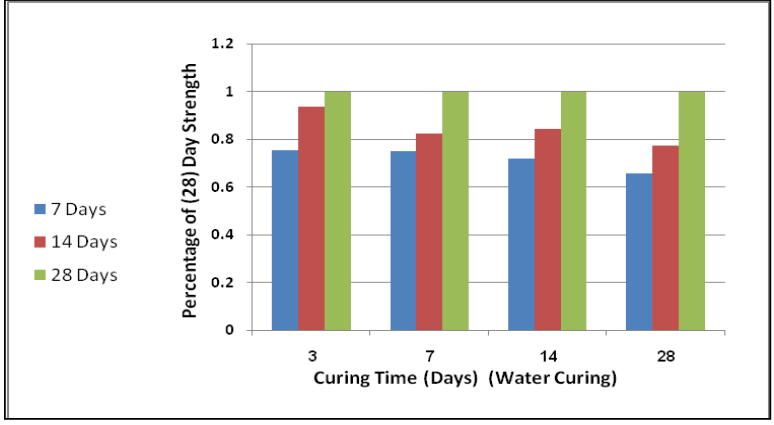

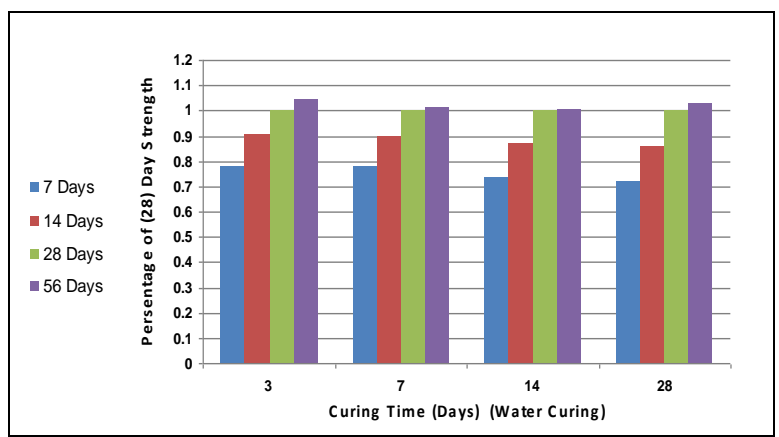

(b) Mix M3

(c) Mix M4

Fig.(10) Percentage of splitting strength to 28-days for different curing regime 


\section{Flexural Strength}

The flexural strength were carried out by testing prisms (100x100x500mm) with span $400 \mathrm{~mm}$ and two point loads applied at the age of 28 days. The results for SCC mixes M1 and M3 shown in Fig.(11), the results show that mix M1 gave more values of flexural strength than mix M3 for all curing regime, the percentage of the flexural strength of mix M1 to that of mix M3 were (12.4,9.6,8 and 7.3) for water curing (3,7,14 and 28) days respectively. The results show that the flexural strength at the water curing time (3,7and 14) days to that at 28 days water curing were $(81.7,86.9$ and 91.9), (77.2, 84.7 and 91.3) for mixes M1and M3 respectively. Fig. (12) shows the relation between the flexural strength and the splitting strength, the relation is approximately linear.

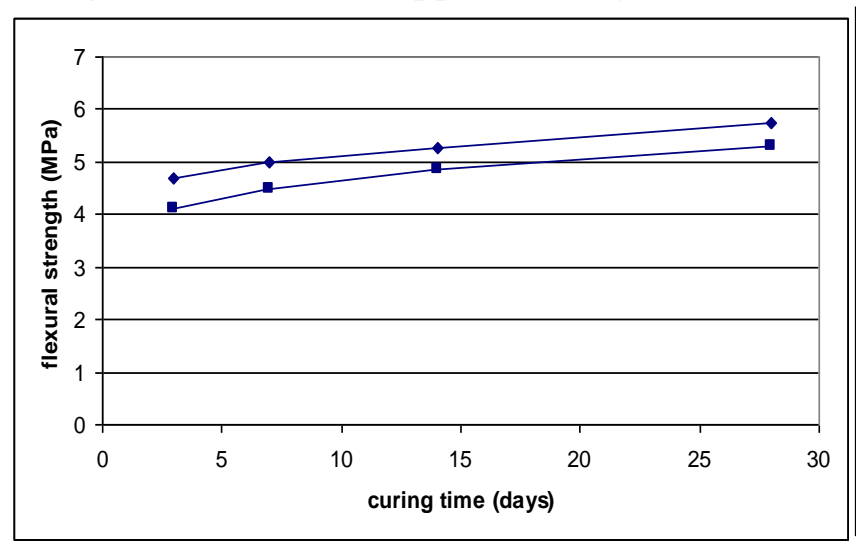

Fig.(11) Variation of flexural strength with

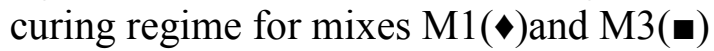

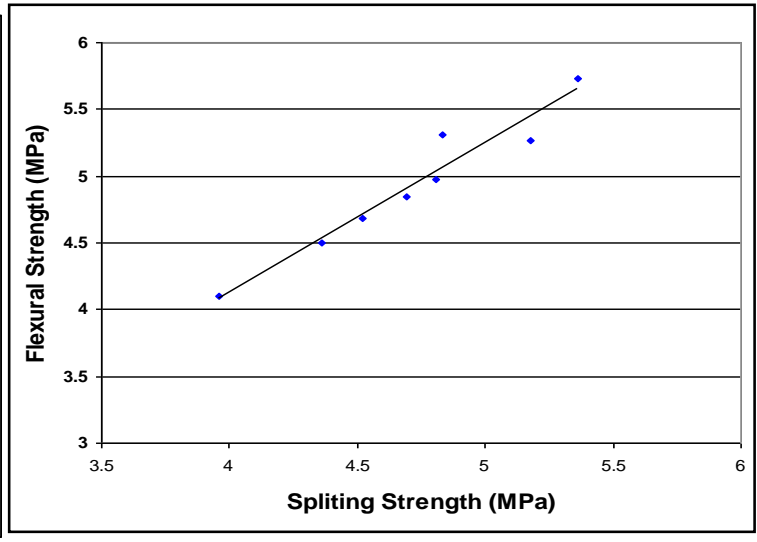

Fig.(12) Relation between the flexural strength and splitting strength

\section{Modulus of elasticity}

The modulus of elasticity of mixes M1 and M3 were measured by using cylinders $(150 \mathrm{~mm}$ diameter, 300mm height) according to the ASTM specifications [13] as shown in Figure 13, the cylinder were capping to make sure that the load applied axially.

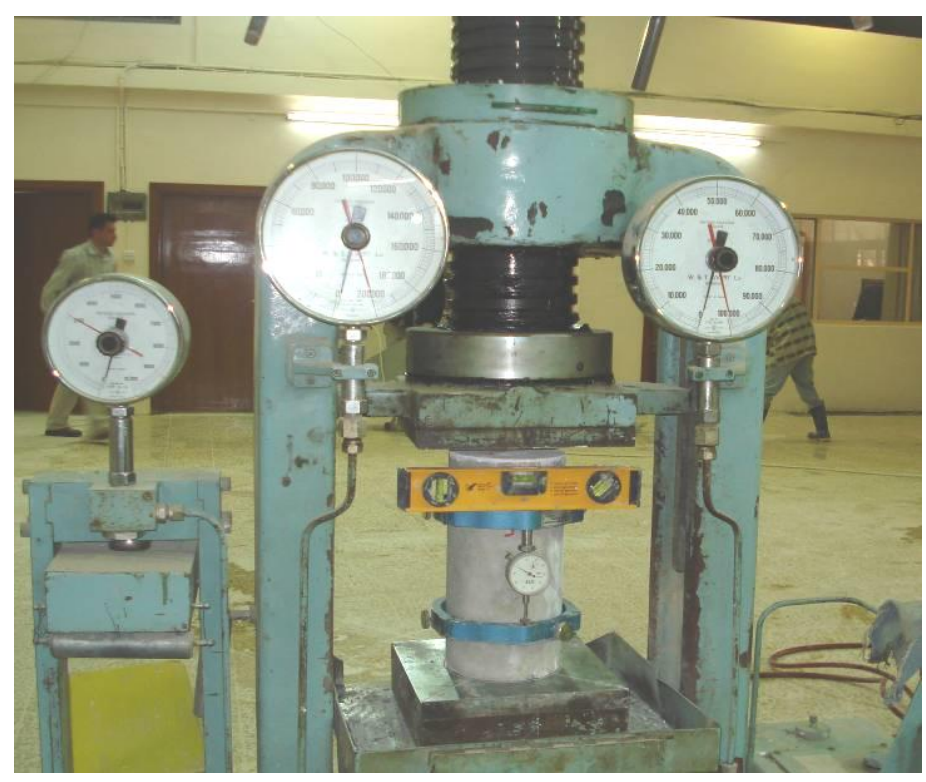

Figure (13) Modulus of elasticity test 
Table 8 shows the result of modulus of elasticity for mixes M1and M3 for different curing regimes (it is worth noting that each results in Table 8 is the average of three cylinders tests), the specimens were tested at the age of 28-days. The results show that mix M1 gave more value of modulus of elasticity than mix M3 for all curing regime, this may be attributed to high cement content of mix M1.

The results show that the modulus of elasticity at three days water curing is $95.5 \%$ and $94.5 \%$ of that of 28-days for mixes M1and M3 respectively, this indicate that the curing regime did not affect the value of the modulus of elasticity of SCC .

Table ( 8) Modulus of elasticity of Mix M1 and M3

\begin{tabular}{|l|c|c|c|c|c|c|c|c|}
\hline Curing time (days) & \multicolumn{2}{|c|}{3} & \multicolumn{2}{c|}{7} & \multicolumn{2}{c|}{14} & \multicolumn{2}{c|}{28} \\
\hline Mix & M1 & M3 & M1 & M3 & M1 & M3 & M1 & M3 \\
\hline Cylinder strength & 39.9 & 36.8 & 42.9 & 38.3 & 45.3 & 42.5 & 47.9 & 44.6 \\
\hline $\begin{array}{l}\text { Modulus of } \\
\text { elasticity (MPa) }\end{array}$ & 28140 & 27280 & 28697 & 27800 & 29080 & 28600 & 29480 & 28880 \\
\hline
\end{tabular}

From the experimental results [12] statistical analysis were done by using SPSS program to get modulus of elasticity formula similar to ACI equation [11]

$$
\begin{array}{lr}
E_{S C C}=4383 \sqrt{f_{c}^{\prime}} & \mathrm{R}^{2}=0.998 \\
E_{N C}=4730 \sqrt{f_{c}^{\prime}} & \text { ACI }(318-08)
\end{array}
$$

$f_{C}^{\prime}=$ Cylinder compressive strength at 28-days

the factor (4383) of the above equation was less than that of ACI equation which is( 4730), for normal concrete, so the modulus of elasticity of SCC is less than modulus of elasticity of normal concrete, and this may be attributed to the presence of fine materials more than in normal concrete.

Fig.(14) shows the ascending part of the stress-strain relationships in compression, for mixes M1 and M3, the general trend for both curves is the same as that for conventional concrete. The nonlinear behaviour starts at $40 \%$ and $55 \%$ of the compressive strength for mixes M1 and M3 respectively.
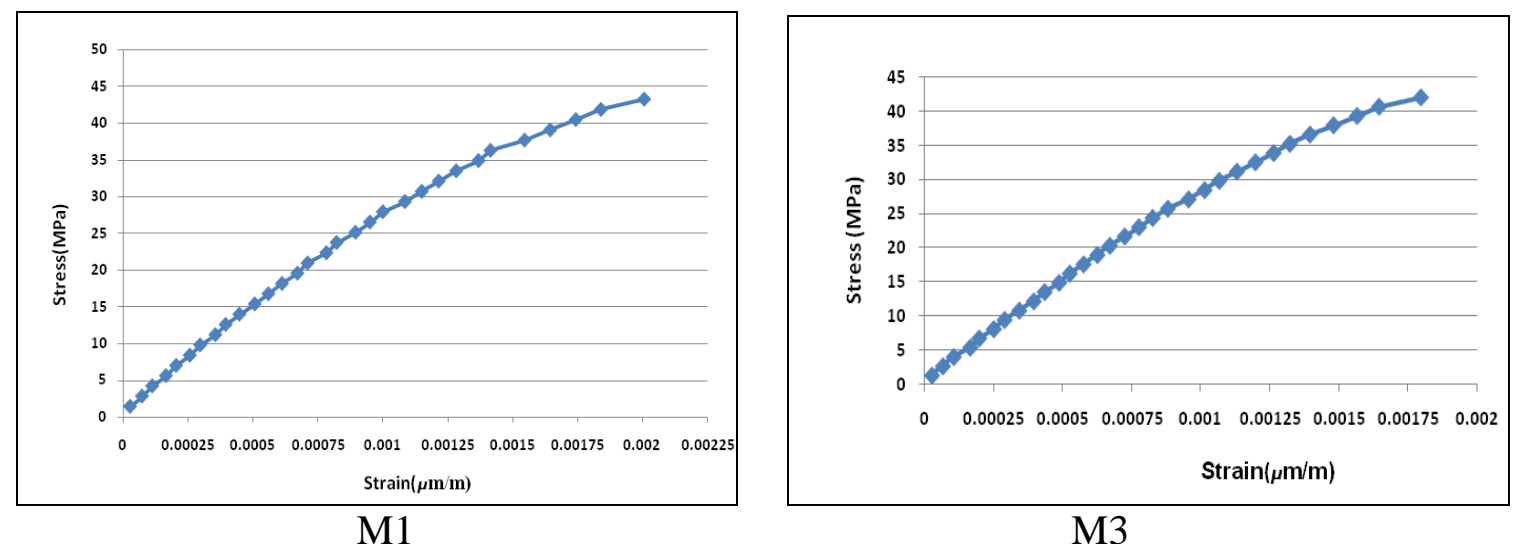

Fig.(14) Stress - strain relationship in compression for mixes M1 and M3 


\section{Porosity of SCC}

Fig.(15) shows the air voids of SCC mix M3and normal concrete mix M4, the figures show that the voids volume in normal concrete greater than that of SCC and the distribution of coarse aggregate in SCC is homogenous.

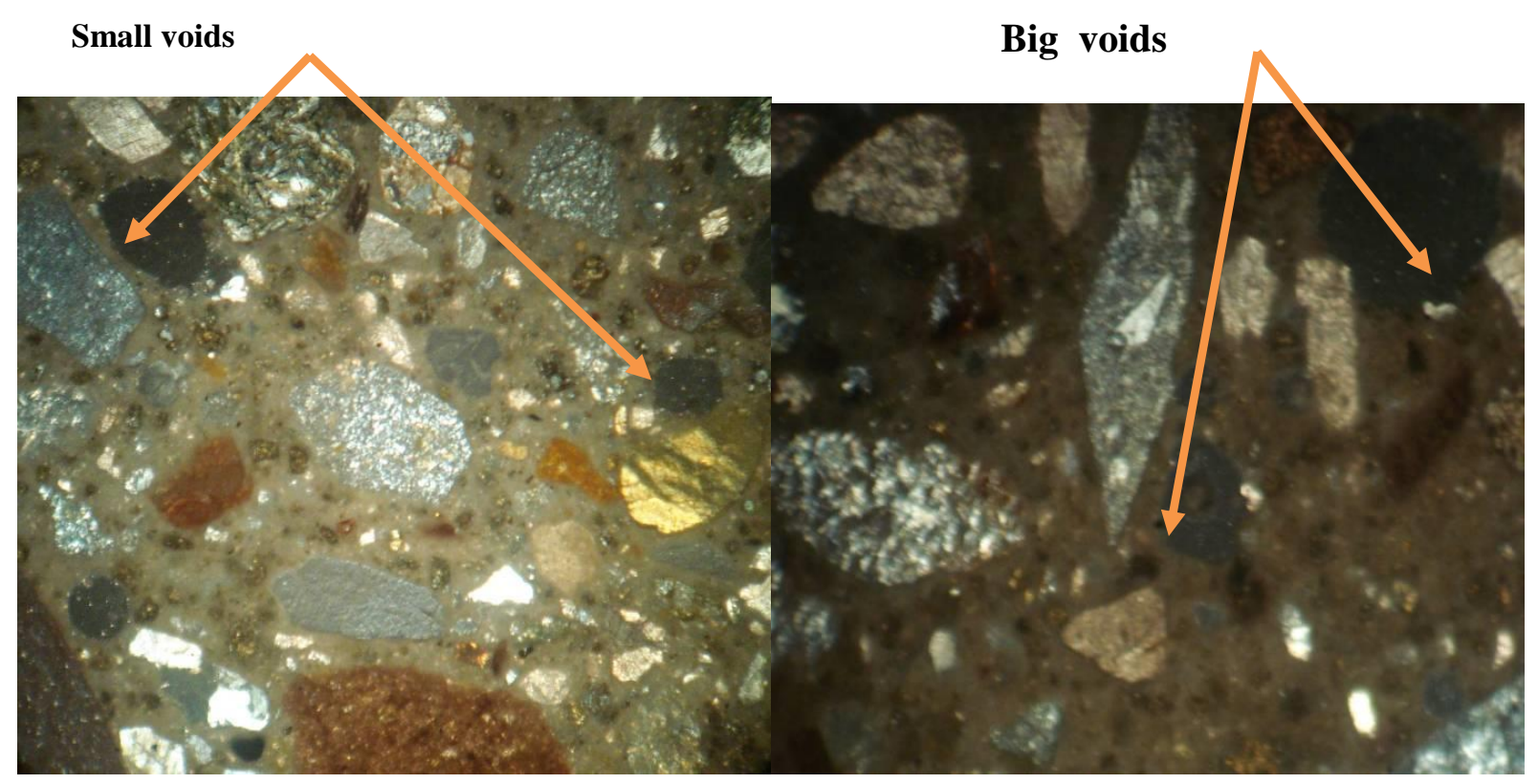

(a) SCC mix M3

(b)Normal mix M4

Fig.(15) air voids in the SCC mix and normal concrete

\section{Mode of failure}

Fig (16) shows the failure mode of the tested specimens in compression, multi- cracks appears on the cubes, and shear cracks appears on the cylinders. Figure (17) shows the failure mode in splitting and the homogeneous distribution of the coarse aggregates. The Figure shows also the splitting of some of the coarse aggregate which may be attributed to the high bond between the cement paste and the aggregate.

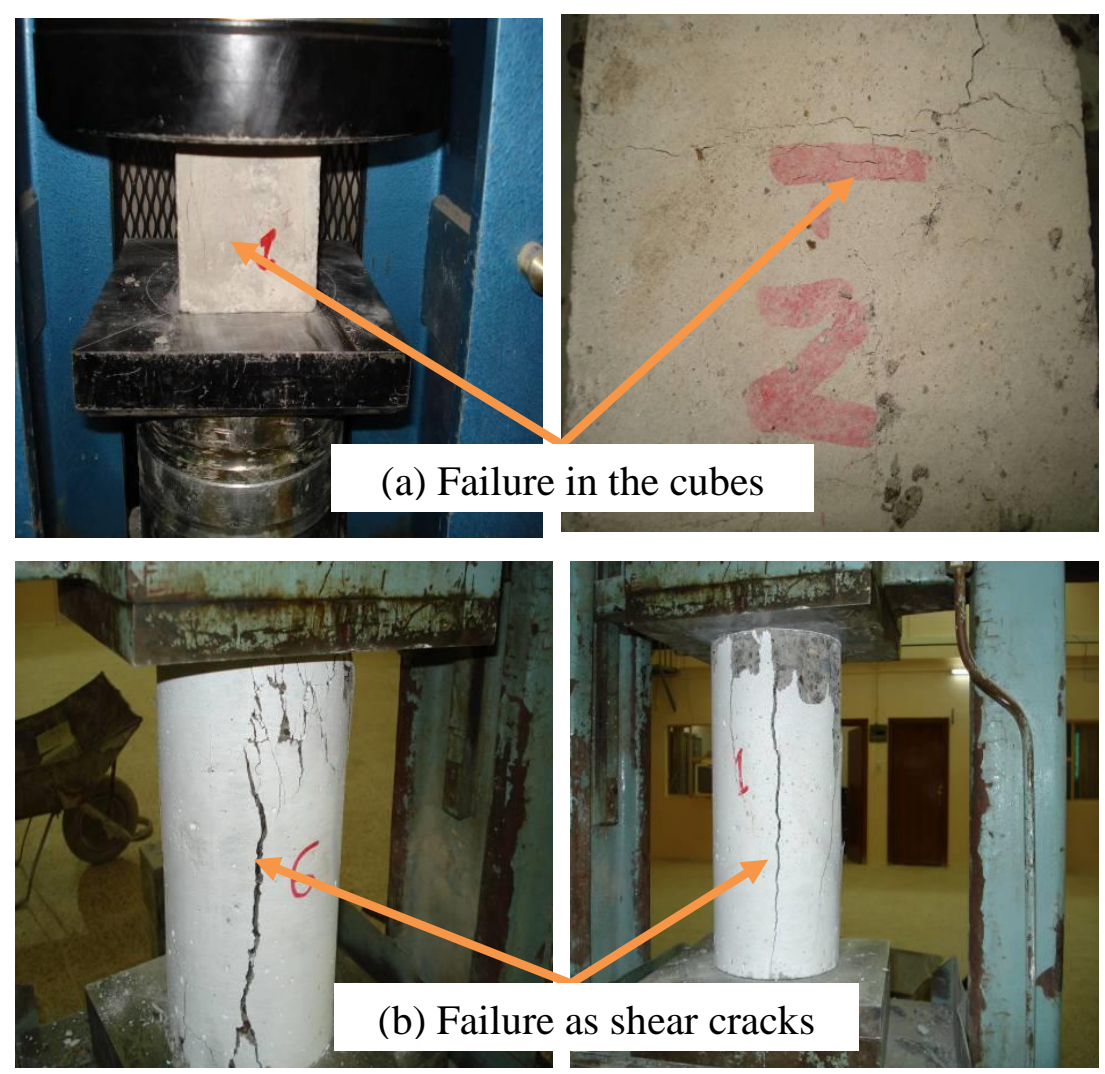

Figure (16) Failure modes in compression, (a) cubes, (b) cylinders 


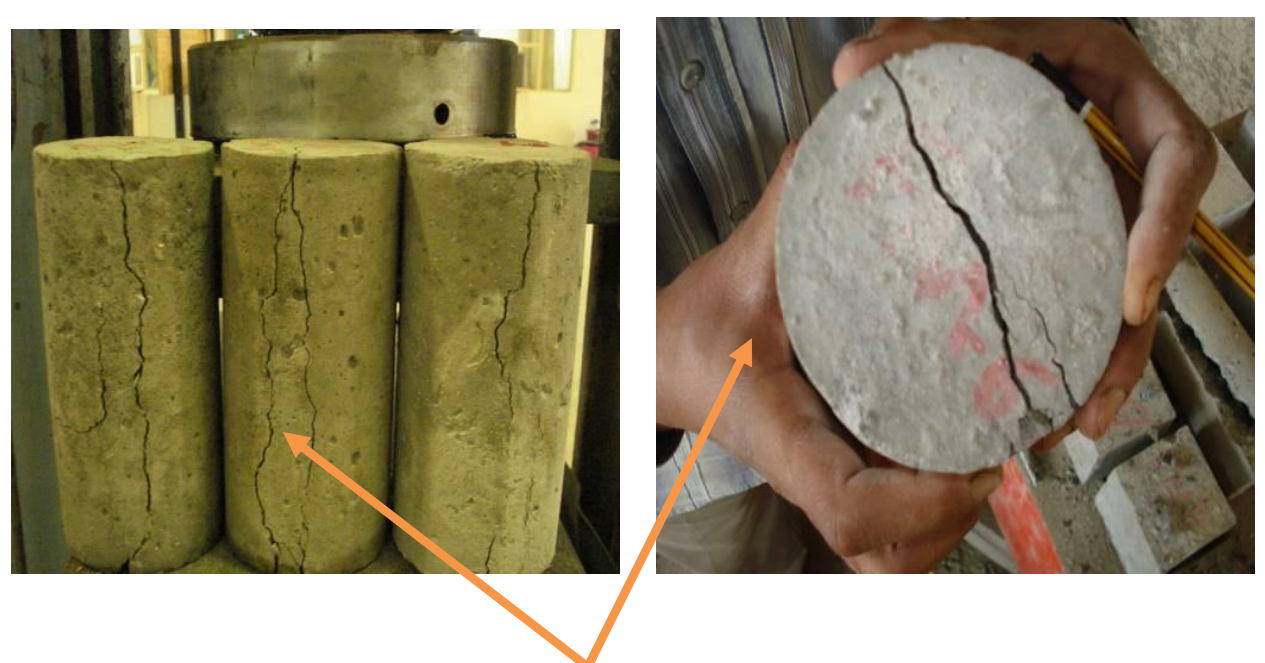

Failure in the splitting test

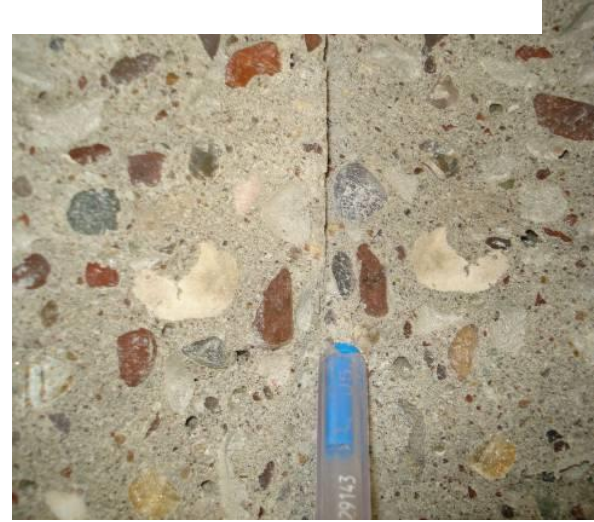

Homogenous distribution of the coarse aggregates

Figure (17) Failure modes in splitting

\section{Conclusions}

1-The clinker dust can be used as cement replacement to get self compacting concrete.

2-The compressive strength develop at early ages for SCC mixes (the compressive strength at 14 days about more than $85 \%$ of that at 28 -days) more than normal concrete (. (the compressive strength at 14 days about $76 \%$ of that at 28 -days).

3 -Water curing regime has slight effect on the of compressive strength for SCC mixes.

4-The presence of clinker dust in mix gave high compressive and less workability results than the mixes with limestone dust.

5- The tensile splitting strength is higher for SCC mixes than for normal concrete

6- SCC gave less value of modulus of elasticity about $92 \%$ of that of normal concrete.

7- The size of voids is less in SCC than that of normal concrete.

More research should be done on the clinker dust to improve the fresh properties of self

Compacting concrete.

\section{REFERENCES}

[1] Aggarwal, P., Siddique, R., Aggarwal, Y., and Mgupta, S.,(2008) Self-Compacting concrete-procedure for mix design, Leonardo Electronic Journal of Practices and Technologies, Issue 12, January, pp. 15-24. 
[2] Bouzoubaa, N., and Lachemi, M.,(2001) Self Compacting concrete incorporating highvolumes of class F fly ash: preliminary results, Cement and Concrete Research, Vol. 31, No. 3, Mar. pp. 413-420.

[3] Collepardi, M., Borsoi, A., Collepardi, S., and Troli, R.,(2005) Strength, shrinkage and creep of SCC and flowing concrete, second north American conference on the design and use of self-consolidating concrete, fourth international RILEM symposium on selfcompacting concrete, Edited by Shah, 2005, pp. 911-919.

[4] Corinaldesi, V., Moriconi, G., and Naik, T. R., (2005) Characterization of marble powder for its use in mortar and concrete, Report No.CBU--09, International Symposium, October 5-7, Toronto, Canada.

[5] Felekoglu, B., Turkel, S., and Baradan, B., (2007) Effect of water/cement ratio on the fresh and hardened properties of self-compacting concrete, Building and Environment, Vol. 42, pp. 1795-1802.

[6] Bager, D. H., Geiker, M. R., and Jensen, R. M., (2008) Rheology of self-compacting mortars-influence of particle grading, NCF, 29-4, pp. 1-14.

[7] Central Office for Measurement and Quality Control (1984) Properties of ordinary port land cement, IQ5, Iraqi Specifications.

[8] British Standard institution 882(1992), Aggregates from Natural Source of Concrete.

[9] EFNARC (2002) European specification and guide line for self-compacting concrete, February.

[10] ERMCO (2005) The European guidelines for self-compacting concrete specification, Production and Use, May.

[11] ACI Committee 318(2008), Building Cod Requirements for Structural Concrete.

[12] Alharbi, M. A.,[2008], "Effect of Different Curing Conditions on Some Properties of Self-Compacting Concrete" M. Sc. Thesis, Mosul University, Iraq.

The work was carried out at the college of Engineering. University of Mosul 